\title{
THE IDENTIFICATION OF LHERZOLITIC CR-DIOPSIDES IN KIMBERLITE EXPLORATION PROGRAMS: EXAMPLES FROM INDICATOR MINERAL SURVEYS CARRIED OUT IN THE PROVINCE OF ONTARIO
}

\author{
Dave Crabtree $^{1}$, Tom Morris ${ }^{2}$, John Ayer ${ }^{1}$ and Ron Sage ${ }^{3}$ \\ ${ }^{1}$ Ontario Geological Survey, Canada; ${ }^{2}$ Superior Diamonds Inc., Canada; ${ }^{3}$ Sault St. Marie, Canada
}

\section{INTRODUCTION}

Over the past decade the Ontario Geological Survey (OGS) has been engaged in a number of broad regional kimberlite indicator mineral (KIM) surveys carried out over structurally favorable terrain in the northern part of the province. The location of these surveys together with the type of sampling media is shown in Figure 1. Modern alluvium has been the most commonly utilized sampling media since it provides a fairly rapid and cost effective way of evaluating the potential of any particular region to host kimberlite. Consistent sampling methods and mineral processing techniques were employed for each of the surveys .
The picking results from the heavy mineral concentrates clearly show that the regional background counts for Cr-diopsides in some of these areas can be high. This can be problematic from an exploration standpoint since the identification of bona fide KIMs may require that large numbers of grains are analysed by electron microprobe in order to isolate important compositions.

Furthermore, the common occurrence of Cr-diopside in alluvial samples, coupled with poorly understood techniques for isolating $\mathrm{Cr}$-diopsides associated with high pressure xenoliths, can severely hamper the exploration geologist. The purpose of this presentation is to shed new light on some advances that have been

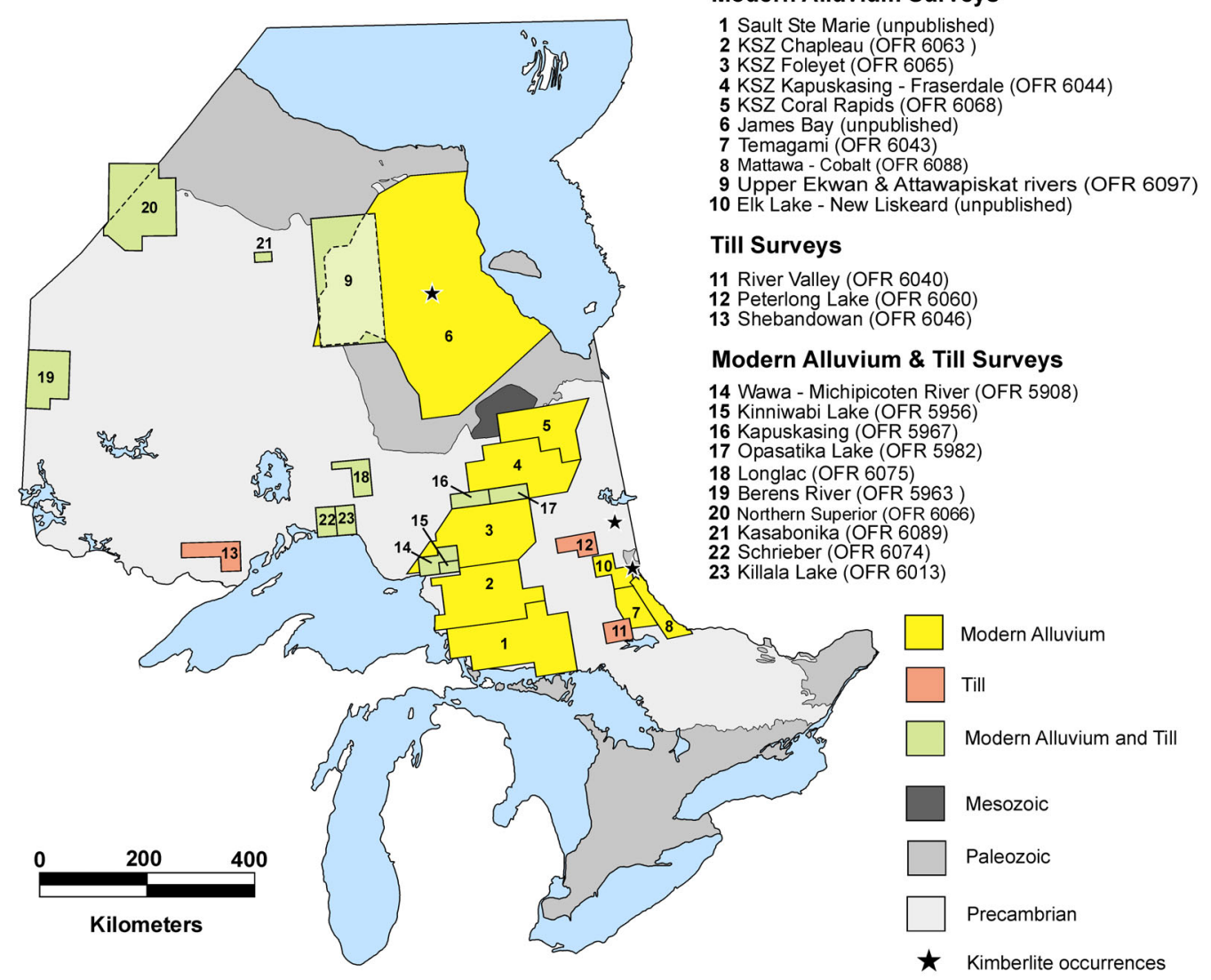

Figure 1. Location of regional indicator mineral surveys carried out by the Ontario Geological Survey (OGS) in the province of Ontario. 
made in identifying important compositional constraints that can greatly improve our ability to identify $\mathrm{Cr}$ diopsides from mantle xenoliths.

\section{THE ROLE OF CR-DIOPSIDE IN DIAMOND EXPLORATION PROGRAMS}

The presence of Cr-diopsides in kimberlite intrusions is the result of the entrainment of clinopyroxene bearing mantle xenoliths that were sampled during the eruption process. The dissagregation of these xenoliths during emplacement of the kimberlite and the subsequent erosion of kimberlite pipes over time is the mechanism by which these minerals are dispersed in the secondary environment. Cr-diopsides are therefore considered to be foreign xenocrysts that are not directly associated with kimberlitic magmatism. The fact that $\mathrm{Cr}$-diopsides are by definition not prevalent in harzburgites suggests that the recovery of this mineral in overburden sampling programs will yield little information about the diamond potential of any particular region under survey.

Nevertheless, the recovery of numerous Cr-diopsides in alluvial samples may be important since it could suggest that a xenolith rich source has been sampled in the secondary environment. For this reason alone, the recovery of $\mathrm{Cr}$-diopside in exploration samples should not be ignored. However, compositional overlaps with Cr-diopsides crystallized at lower pressures makes the task of isolating those grains associated with lherzolites a difficult one. This is further complicated by the fact that Cr-diopside is not uncommon in many of the heavy mineral concentrates isolated from samples collected in northern Ontario.

In the past, the most common approach for isolating lherzolitic $\mathrm{Cr}$-diopsides has been to utilize relatively simple $\mathrm{Cr}_{2} \mathrm{O}_{3}$ thresholds. However, with access to rapidly expanding mineral data bases it has become evident the $\mathrm{Cr}$-diopsides from non kimberlitic sources may also be elevated with respect to $\mathrm{Cr}_{2} \mathrm{O}_{3}$, thereby necessitating a new technique for isolating compositions that are characteristic of deep mantle sources.

\section{IMPORTANT COMPOSITIONAL CONSTRAINTS}

After careful examination of a relatively large clinopyroxene data base it was decided that a ternary projection of $\mathrm{Al}-\mathrm{Cr}-\mathrm{Na}$ (atomic proportions) would greatly improve the ability of the exploration geologist to isolate important Cr-diopside compositions (Morris et al. 2002). The projection shown in Figure 2 illustrates the position on the ternary diagram of the most common molecular sinks for $\mathrm{Al}, \mathrm{Na}$ and $\mathrm{Cr}$. While there are many possible substitutions (see Morimoto et al. 1988), the ones shown here include: $\mathrm{CaAlSi}_{2} \mathrm{O}_{6}$ (calcium tchermak or CATS); $\mathrm{NaAlSi}_{2} \mathrm{O}_{6}$ (jadeite); $\mathrm{NaFe}^{3+} \mathrm{Si}_{2} \mathrm{O}_{6}$ (aegerine); $\mathrm{NaCrSi}_{2} \mathrm{O}_{6}$ (kosmochlor); and $\mathrm{CaCrAlSiO}_{6}$ (CrCATS). The possible substitution of $\mathrm{CaCr}_{2} \mathrm{SiO}_{6}$ in the clinopyroxene structure should also be considered (Vredevoogd \& Forbes 1975). There are many factors that control the entry of these molecules into the mineral structure including pressure and temperature (P-T) conditions, starting compositions of crystallizing melts and element partition coefficients between melt and precipitating phases.

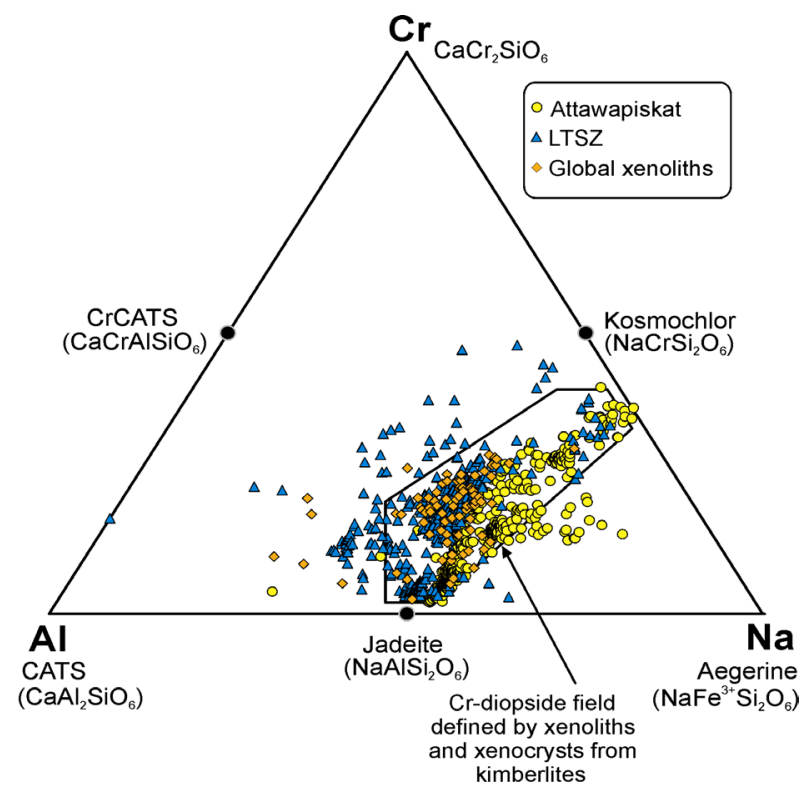

Figure 2: Na-Al-Cr ternary plot for $\mathrm{Cr}$-diopsides from xenocrysts and xenoliths in kimberlites. Abbreviation is as follows: LTSZ, Lake Timiskaming Structural Zone

One of the most important aspects of using the Al-Na$\mathrm{Cr}$ ternary approach is that the enhanced solubility of any one of these molecules in the clinopyroxene structure will have the effect of influencing the projected composition on the ternary diagram. Experimental studies suggest that the projected compositions of clinopyroxenes that have equilibrated at mantle pressures should be strongly influenced by the position of the jadeite molecule on the Al-Cr-Na ternary plot (Walter and Presnall 1994).

In fact the distribution of the majority of clinopyroxene xenocrysts recovered from kimberlites plot along a 
compositional line of control between the jadeite $\left(\mathrm{NaAlSi}_{2} \mathrm{O}_{6}\right)$ and kosmochlor $\left(\mathrm{NaCrSi}_{2} \mathrm{O}_{6}\right)$ molecules (Figure 2). This suggests that the entry of $\mathrm{Al}, \mathrm{Na}$ and $\mathrm{Cr}$ into the clinopyroxene structure at elevated pressures is controlled almost entirely by these two molecules. More importantly, it implies that at these pressures, most $\mathrm{Al}$ enters the clinopyroxene structure in the form of the jadeite molecule and not as CATS. This is supported by the fact that the atomic proportions of $\mathrm{Al}$, $\mathrm{Na}$ and $\mathrm{Cr}$ in the majority of clinopyroxenes recovered from Ontario kimberlites have near 1:1 Na: $\mathrm{Al}+\mathrm{Cr})$ ratios.

While the ternary approach is effective at screening $\mathrm{Cr}$ bearing clinopyroxenes from many other types of environments (see Morris et al. 2002 for a review) there is evidence from some of the regional surveys that an additional filter is required to help remove large populations of $\mathrm{Cr}$-diopsides that in some cases overlap the field identified here for kimberlites. Samples collected from the Kapuskasing Structural Zone (KSZ) have on average relatively high $\mathrm{Cr}$-diopside counts, and a large population of grains overlaps with the field identified for kimberlitic xenocrysts and xenoliths (Figure 3). The KSZ survey (Figure 1: areas 2, 3, 4, 5, $14,15,16$ and 17) probably represents the most problematic region encountered by the OGS with regards to $\mathrm{Cr}$-diopside recovery, since a large number of the Cr-diopsides are likely derived from the high grade terrain (Ontario Geological Survey 2001).

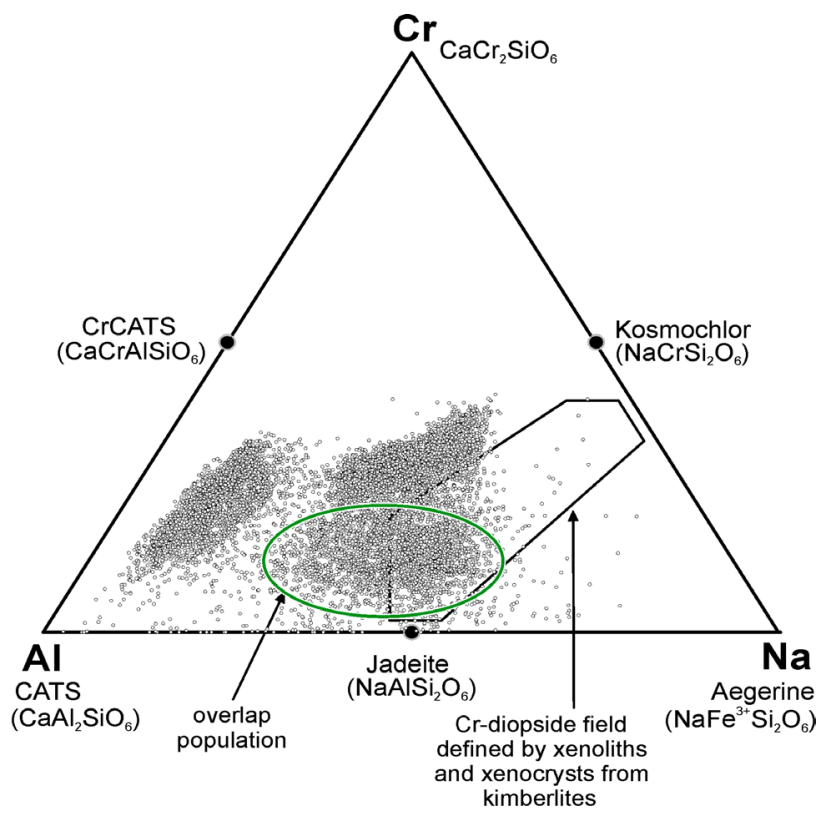

Figure 3: Al-Na-Cr ternary plot for $\mathrm{Cr}$-diopsides from the Kapuskasing Structural Zone (KSZ) survey.
In order to overcome this problem an additional filter is required to enhance the probability of isolating grains with compositional traits typical of those observed in lherzolites. Examination of xenocryst and xenolith data from kimberlites suggests that a binary projection of atomic $\mathrm{Ca} /(\mathrm{Ca}+\mathrm{Mg})$ vs. $\mathrm{Na}_{2} \mathrm{O}$ (wt \%) could prove to be a very useful way to further filter out $\mathrm{Cr}$-diopsides from non-kimberlitic sources. Figure 4 illustrates the compositional trend for $\mathrm{Cr}$-diopside xenocrysts isolated from the Attawapiskat kimberlites as well as from a number of globally occurring xenoliths. A boundary that isolates the population associated with kimberlites has been highlighted, although it should be noted that this field is preliminary, and may be subject to modification as additional data becomes available.

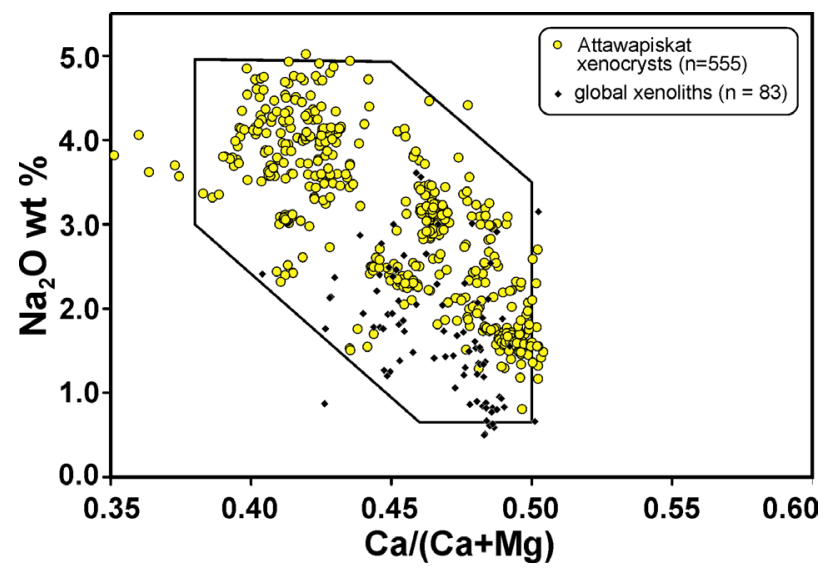

Figure 4: $\mathrm{Ca} /(\mathrm{Ca}+\mathrm{Mg})$ vs. $\mathrm{Na}_{2} \mathrm{O}$ plot for $\mathrm{Cr}$-diopsides from xenocrysts and xenoliths in kimberlites.

One of the interesting features of this diagram is that the effects of both pressure and temperature may play a role in the distribution of the observed trend. Temperature effects will largely depend on a number of key assumptions, such as the need for coexisting clinopyroxene and orthopyroxene, in order to observe the exchange reaction of $\mathrm{Ca}$ and $\mathrm{Mg}$ between these 2 phases (see Carswell and Gibb 1987). Increasing temperature (at constant pressure) should produce a trend on this diagram that proceeds from right to left (increasing $\mathrm{Mg}$ and decreasing $\mathrm{Ca}$ ), assuming that clinopyroxene is in equilibrium with orthopyroxene. The role of pressure on the entry of $\mathrm{Na}$ into the diopside structure has been examined for simplified lherzolite systems (Walter and Presnall 1994). Their study shows that with increasing pressure, the solubility of jadeite in the clinopyroxene structure also increases. Increasing pressure will therefore be observed as a trend which proceeds from bottom to top on this diagram (increasing $\mathrm{Na}_{2} \mathrm{O}$ concentration). 
The projection of the KSZ clinopyroxene data onto the $\mathrm{Ca} /(\mathrm{Ca}+\mathrm{Mg})$ vs. $\mathrm{Na}_{2} \mathrm{O}$ plot is shown in Figure 5 . A total of 8700 diopsides were isolated from heavy mineral concentrates collected during the KSZ survey. Of these, 80 have compositions that are characteristic of those observed in the Attawapiskat kimberlites and global xenolith populations. It is interesting to note that the large overlap cluster identified in Figure 4 has a higher $\mathrm{Ca} /(\mathrm{Ca}+\mathrm{Mg})$ ratio than the field delineated for kimberlites, and this population is effectively screened using this technique. While the origin of this cluster is not known, the 2 stage approach in filtering these data with both ternary and binary projections is successful in resolving this problematic overlap. Also noteworthy are the other clusters that have elongate distributions running from left to right (variable $\mathrm{Ca} /(\mathrm{Ca}+\mathrm{Mg})$ ratios) on Figure 5. Although speculative, it is conceivable that these trends could be the result of cooling during the crystallization of clinopyroxenes from shallow magmas.

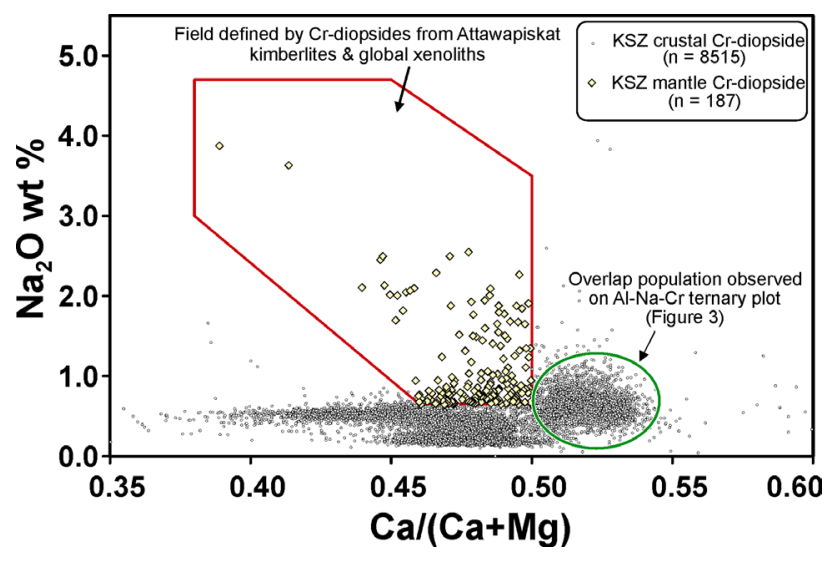

Figure 5: $\mathrm{Ca} /(\mathrm{Ca}+\mathrm{Mg})$ vs. $\mathrm{Na}_{2} \mathrm{O}$ plot for $\mathrm{Cr}$-diopsides recovered from the Kapuskasing Structural Zone (KSZ) survey.

This 2 stage approach has also proved very successful at isolating populations associated with kimberlites in the Mattawa-Cobalt (Figure 1: area 8) and Temagami (Figure 1: area 7) survey. Both of these areas are located south (down ice) of the known kimberlite occurrences in the New Liskeard area. The screening of data from the Mattawa-Cobalt area (Reid 2002) has enabled us to identify unique geographic associations for the various clusters of data. Those grains identified using the 2 stage approach shown here are concentrated in the northern part of the survey area due south of the known kimberlite occurences, and in many cases coexist with other KIMs such as $\mathrm{Cr}$-pyropes and $\mathrm{Mg}$ ilmenites.

The only known difficulty with the binary discriminant diagram is that $\mathrm{Cr}$-diopsides from lherzolites found in alkalic basalts also plot within the field identified for lherzolitic compositions recovered from kimberlites. However, this overlap is less problematic on the Al-NaCr ternary plot, and the use of a 2 stage approach should assure that compositions typical of alkalic basalt hosted lherzolites are effectively screened.

\section{SUMMARY}

The results of regional indicator mineral sampling programs indicate that $\mathrm{Cr}$-diopside populations can be quite abundant in the immature sediments typical of the Canadian shield environment. The 2 stage method presented here for screening clinopyroxene data appears to be a good way of isolating $\mathrm{Cr}$-diopside compositions typical of those observed in kimberlitic hosted lherzolite xenoliths. Nevertheless, the task of identifying these important compositions can be both time consuming and expensive. Ultimately the decision on how to proceed will depend on the region under survey and also on economic factors. In parts of the province where the regional background abundance of Cr-diopside is low, such as over the Paleozoic terrain of the Hudson and James Bay lowlands, the ability to properly isolate lherzolitic Cr-diopsides from heavy concentrates is not expected to be problematic.

The results presented here should be considered as a good first step at delineating compositional constraints for high pressure $\mathrm{Cr}$-diopsides. It should be noted however, that the majority of the data utilized here is derived from heavy mineral concentrates. It is generally assumed that most of these xenocrysts are derived from lherzolites, but it is quite likely that those associated with wherlites and pyroxenites are probably also represented. Furthermore, there is insufficient data to be able to distinguish between those compositions that are associated with spinel or garnet bearing peridotite assemblages. This would be highly desirable since the ability to identify $\mathrm{Cr}$-diopsides from garnet bearing assemblages could be applied to single clinopyroxene thermobarometric calculations. Ultimately this information could then be used to estimate P-T conditions at the source region, creating a unique opportunity to evaluate the potential of the sub-cratonic lithosphere to host diamonds in any given area of interest. 


\section{REFERENCES}

Carswell, D.A. and Gibb, F.G.F. 1987. Evaluation of mineral thermometers and barometers applicable to garnet lherzolite assemblages. Contributions to Mineralogy and Petrology, 95, 218-227.

Morimoto, N., Fabries, J.A., Ferguson, A.K., Ginzburg, I.V., Ross, M., Seifert, F.A., Zussman, J., Aoki, K., and Gottardi, G. 1988. Nomenclature of pyroxenes. Mineralogical Magazine, 52, 535-550.

Morris, T.F., Sage, R.P., Ayer, J.A., and Crabtree, D.C.. 2002. A study of clinopyroxene composition: Implications for kimberlite exploration. Geochemistry, Exploration, Environment, Analysis, 2, no. 4, pp. 321331.

Ontario Geological Survey 2001. Results of modern alluvium sampling, Coral Rapids, northeastern Ontario: Operation Treasure Hunt - Kapuskasing Structural Zone; Ontario Geological Survey, Open File Report 6068 .

Reid, J.L. 2002. Regional modern alluvium sampling survey of the Mattawa-Cobalt corridor, northeastern Ontario; Ontario Geological Survey, Open File Report 6088.

Vredevoogd, J.J. and Forbes, W.C., 1975. The system diopside-ureyite at $20 \mathrm{~kb}$. Contributions to Mineralogy and Petrology, 52, 147-156.

Walter, M. J. and Presnall, D.C. 1994. Melting Behaviour of simplified lherzolite in the system $\mathrm{CaO}-\mathrm{MgO}-\mathrm{Al}_{2} \mathrm{O}_{3}$ $\mathrm{SiO}_{2}-\mathrm{Na}_{2} \mathrm{O}$ from 7 to 35 kbar. Journal of Petrology, 35, 329-359.

Contact: D Crabtree, Ontario Geological Survey, 933 Ramsey Lake Road, Sudbury, Ontario, P3E 6B5, E-mail:

dave.crabtree@ndm.ndm.gov.on.ca 